\title{
BIODEGRADASI JERAMI PADI OLEH Penicillium spp. DENGAN VARIASI UKURAN PARTIKEL JERAMI
}

\author{
Asri Peni Wulandari ${ }^{1}$, Ema Wulandini, Ida Indrawati \\ Laboratorium Mikrobiologi, Departemen Biologi, FMIPA, Universitas Padjadjaran \\ ${ }^{1}$ asri.peni@unpad.ac.id
}

Diterima : 12 Mei 2014, Revisi akhir : 23 Oktober 2014, Disetujui terbit : 3 November 2014

\section{BIODEGRADATION OF RICE STRAW USING Penicillium spp. WITH PARTICLE SIZE VARIATION IN BIOPULPING PROCESS}

\begin{abstract}
Biodegradation of rice straw was performed by solid state fermentation using two isolates Penicillium to assess degradation time and effect of particle size on the growth and enzyme production. Biodegradation of the straw was conducted over 12 days using three straw particle size of 4, 8, and 12 mesh. The results showed that particle size affects the degradation process of rice straw. Delignification influenced by activity of ligninase optimum size of 12 mesh with the degradation time in 2-4 days. Penicillium sp1 produced ligninase with the highest activity $1140 \mathrm{U} / \mathrm{mL}$ (lignin content 55.2\%) and cellulase $140 \mathrm{U} / \mathrm{m}$ (content of cellulose 27.6\%)., while highest ligninase and cellulase activity of Penicillium sp2. $882 \mathrm{U} / \mathrm{mL}$ (lignin content 49.4\%) and $102 \mathrm{U} / \mathrm{mL}$ (content of cellulose 15.9\%).
\end{abstract}

Keywords: biopulping, biodegradation, rice straw, Penicillium spp.

\begin{abstract}
ABSTRAK
Biodegradasi jerami padi telah dilakukan secara fermentasi media padat dengan menggunakan dua isolat Penicillium untuk mengkaji waktu degradasi dan pengaruh ukuran partikel jerami terhadap pertumbuhan Penicillium spp. dan produksi enzim lignoselulolitiknya. Biodegradasi jerami padi dilakukan selama 12 hari dengan menggunakan tiga ukuran partikel jerami 4, 8, dan 12 mesh. Hasil penelitian menunjukkan bahwa ukuran partikel berpengaruh terhadap proses degradasi jerami padi. Delignifikasi dipengaruhi oleh aktivitas ligninase yang optimum pada ukuran 12 mesh dengan waktu degradasi 2-4 hari. Penicillium sp1. menghasilkan ligninase dengan aktivitas tertinggi $1140 \mathrm{U} / \mathrm{mL}$ dan selulase $140 \mathrm{U} / \mathrm{mL}$, sehingga dapat mendegradasi lignin sebanyak 55,2\% dan selulosa $27,6 \%$, sedangkan aktivitas tertinggi dari ligninase dan selulase dari Penicillium sp2., masing-masing adalah $882 \mathrm{U} / \mathrm{mL}$ dan $102 \mathrm{U} / \mathrm{mL}$ dengan kadar lignin yang terdegradasi adalah 49,4\% dan selulosa $15,9 \%$.
\end{abstract}

Kata kunci: biopulping, biodegradasi, jerami padi, Penicillium spp.

\section{PENDAHULUAN}

Jerami padi merupakan limbah berbahan lignoselulosa yang disusun oleh tiga jenis polimer utama yaitu 32,1\% selulosa, 24\% hemiselulosa, dan 18\% lignin (Howard dkk., 2003). Kandungan lignin yang tinggi pada jerami memerlukan proses degradasi yang cepat dengan memperhatikan kondisi kultur yang optimum terutama penggunaan mikroorganisme yang effektif dalam memproduksi enzim lignoselulolitik dan ukuran partikel substrat.

Quintanar dkk. (2012) menyebutkan bahwa proses biodelignifikasi jerami jagung dengan ukuran partikel jerami 2,30 $\mathrm{mm}$ (sieves No. 8) dan 4,76 mm (sieves No. 4) dengan menggunakan Trametes sp. 44 dapat berpengaruh dalam proses biodelignifikasi jerami jagung selama 12 hari fermentasi. Kausar dkk. (2010) melaporkan bahwa beberapa jenis jamur seperti Aspergillus niger 
dan Trichoderma viride mampu mendegradasi komponen lignoselulosa pada jerami padi. Beberapa jenis jamur seperti Trichoderma, Penicillium, Fusarium, dan Aspergillus mempunyai aktivitas selulolitik, hemiselulolitik, dan ligninolitik yang tinggi (Anindyawati, 2010). Pada penelitian Guisado dkk. (2001) dijelaskan bahwa isolat Penicillium sp. MF24 yang diisolasi dari proses pengomposan sampah organik memiliki aktivitas lignin peroksidase (LiP) $(2419,92 \mathrm{U} / \mathrm{mL})$ dan mangan peroksidase (MnP) $(5,02 \mathrm{U} / \mathrm{mL})$ pada media induksi ABTS (2,2' -azino-bis-3-ethylbenzthiazoline-6sulphonic acid), sedangkan Penicillium sp. MF24 tidak memiliki aktivitas lakase. Selain memiliki aktivitas ligninase, Penicillium sp. mampu menghasilkan aktivitas selulase, seperti yang dinyatakan oleh Howard dkk. (2003), bahwa Penicillium brefeldianum mampu menghasilkan glucanohydrolase yang dapat memecah senyawa selulosa.

Menurut Mtui (2009) dalam meningkatkan laju hidrolisis enzim perlu dilakukan suatu perlakuan awal mengurangi ukuran limbah lignoselulosa. Ukuran partikel menentukan besarnya ruang antar bahan (porositas). Permukaan area yang lebih luas akan meningkatkan kontak antara mikroba dengan bahan sehingga proses dekomposisi akan berjalan lebih cepat.

Dalam penelitian Quintanar dkk., (2012) menunjukan bahwa ukuran partikel mendukung ekspresi enzim selulolitik, hemiselulolitik, dan ligninolitik (Lac, LiP, dan $\mathrm{MnP})$ dengan menggunakan Trametes sp. 44 dalam biodelignifikasi jerami jagung dengan menggunakan Solid State Fermentation selama 12 hari. Ukuran partikel jerami jagung yang digunakan adalah 2,30 $\mathrm{mm}$ (sieves No. 8) dan $4,76 \mathrm{~mm}$ (sieves No. 4). Enzim selulase tertinggi sebesar $21 \mathrm{AU} / \mathrm{mL}$ pada hari ke-8 fermentasi dan ligninase tertinggi berupa lakase (Lac) $225 \mathrm{AU} /$ $\mathrm{mL}$ pada hari ke-5 fermentasi, lignin peroksidase (LiP) $62 \mathrm{AU} / \mathrm{mL}$ pada hari ke-7 fermentasi, dan mangan peroksidase $(\mathrm{MnP}) 11 \mathrm{AU} / \mathrm{mL}$ pada hari ke-12 fermentasi yang dihasilkan pada ukuran partikel 2,30 mm (sieves No. 8).

Hasil uji pendahuluan tentang hasil skrining isolat indigen dari jerami padi menunjukkan bahwa dua isolat Penicillium spp. yaitu Penicillium sp1., dan Penicillium sp2. memiliki aktivitas ligninase dan selulase yang tinggi (data tidak dipublikasikan). Penelitian dilakukan untuk mengkaji waktu degradasi dan enzim dengan aktivitas lignoselulolitik dari dua isolat Penicillium spp. dalam mendegradasi jerami padi pada tiga ukuran partikel jerami yaitu 4, 8, dan 12 mesh dan melihat pengaruh ukuran partikel pada pada persentase kadar lignin dan seulosa yang didegradasi.

\section{BAHAN DAN METODE}

\section{Bahan}

Isolat yang digunakan dalam penelitian ini adalah isolat jamur Penicillium sp1., Penicillium sp2. yang merupakan kultur koleksi di Laboratorium Mikrobiologi, Departemen Biologi, FMIPA, UNPAD. Jerami padi hasil diperoleh dari wilayah Jatinangor, Sumedang.

\section{Penyiapan Bahan Jerami}

Jerami kering dicacah untuk memperkecil ukuran partikel, selanjutnya di-shaker dengan mesin Rotap yang di dalamnya terdapat ayakan dengan variasi ukuran berbeda selama 10 menit (Quintanar dkk., 2012), sehingga tersedia jerami padi berukuran partikel berukuran 4 mesh $(4,76$ $\mathrm{mm}), 8$ mesh $(2,36 \mathrm{~mm})$, dan 12 mesh $(1,70$ $\mathrm{mm})$. Sebelum dilakukan inokulasi, jerami disterilisasi lebih dahulu pada kondisi $121^{\circ} \mathrm{C}, 1$ atm, 30 menit.

\section{Delignifikasi Jerami Padi}

Jerami padi yang telah disiapkan dengan ukuran partikel berbeda-beda ditimbang sebanyak $40 \%(\mathrm{~g} / \mathrm{L})$. Prekultur jamur dengan jumlah $10 \times 10^{8} \mathrm{sel} / \mathrm{mL}$ disuspensikan dalam $\mathrm{NaCl}$ fisiologis steril.

Proses delignifikasi dilakukan dengan memasukkan suspensi jamur pada jerami dengan ukuran partikel jerami padi berbeda, selanjutnya diinkubasi pada suhu $28-30^{\circ} \mathrm{C}$ selama 12 hari. Setiap 1 x 24 jam dihitung aktivitas ligninase dan selulase.

\section{Pertumbuhan Jamur}

Penghitungan sel jamur selama proses delignifikasi dilakukan dengan teknik pengenceran secara bertahap hingga $10^{-10}$. Sebanyak $1 \mathrm{~mL}$ dari tiga pengenceran terakhir dimasukan ke dalam cawan petri steril, kemudian dituang $\pm 20 \mathrm{~mL}$ medium Potato Dextrose Agar 
(PDA). Cawan petri selanjutnya diinkubasi selama 3 hari pada suhu $28-30^{\circ} \mathrm{C}$. Koloni jamur yang tumbuh kemudian dihitung dengan menggunakan rumus berdasarkan Cappucino dan Sherman (2009).

\section{Assay Enzim}

Assay lignin peroksidase dilakukan untuk menghasilkan pola produksi ligninase. Produksi ligninase diukur secara spektrofotometri dengan panjang gelombang $310 \mathrm{~nm}$. Sampel hasil assay ligninase yang dikonversi dengan kurva standar vanillin. Satu unit aktivitas ligninase (U) didefinisikan sebagai jumlah ligninase yang dilepaskan untuk $1 \mu \mathrm{mol}$ vanilin per menit. Unit aktivitas ligninase dihitung dengan rumus berdasarkan Soares dkk. (2001).

Assay enzim untuk selulase dilakukan dengan metode DNS dengan analisis spektofotometri pada panjang gelombang $540 \mathrm{~nm}$. Produksi selulase diukur berdasarkan nilai absorbansi sampel hasil assay selulase yang dikonversi dengan kurva standar glukosa. Satu unit aktivitas selulase (U) didefinisikan sebagai jumlah selulase yang dilepaskan untuk $1 \mu \mathrm{mol}$ glukosa per menit. Unit aktivitas selulase dihitung dengan rumus berdasarkan Soares dkk. (2001).

\section{Analisis Kadar Lignin dan Selulosa}

Penentuan berat lignin dan selulosa dilakukan dengan metode gravimetri, sedangkan penentuan peresentase kadar lignin dan selulosa dihitung dengan Metode ADF (Wulandari dkk., 2013).

\section{HASIL DAN PEMBAHASAN}

Profil Pertumbuhan Penicillium spp. pada Berbagai Ukuran Jerami Padi

Profil pertumbuhan jamur Penicillium sp1. pada ukuran jerami 4, 8, dan 12 mesh menunjukkan pertumbuhan maksimum pada hari ke-2 dan cenderung menurun sampai akhir fermentasi pada hari ke-12. Profil pertumbuhan Penicillium sp1. cenderung mengalami peningkatan jumlah sel jamur selama fermentasi pada ukuran jerami dengan ukuran terkecil (12 mesh). Penicillium sp2. menunjukkan pola pertumbuhan jamur yang paling maksimum pada hari ke-1. Ada kecenderungan pola pertumbuhan Penicillium sp2. adalah sama pada semua ukuran jerami padi yang digunakan. Fase stationer yang panjang terjadi pada hari ke-3 hingga hari ke-8, dan cenderung mengalami penurunan jumlah sel jamur terjadi dari hari ke-9 hingga hari ke12. Ukuran mesh yang berbeda memberikan pola pertumbuhan yang hampir sama, ketiga ukuran jerami mengalami fase stasioner (Gambar 1).

\section{Profil Produksi Enzim Ligninase dan Selulase pada Berbagai Ukuran Jerami}

Profil produksi ligninase dari Penicillium spp. dari hasil fermentasi jerami dengan menggunakan variasi ukuran jerami 4, 8, dan 12 mesh ditampilkan pada Gambar 2.

Penggunaan Penicillium sp1. Pada fermentasi jerami dengan ukuran 4, 8, dan 12 mesh menunjukkan pola produksi ligninase maksimum
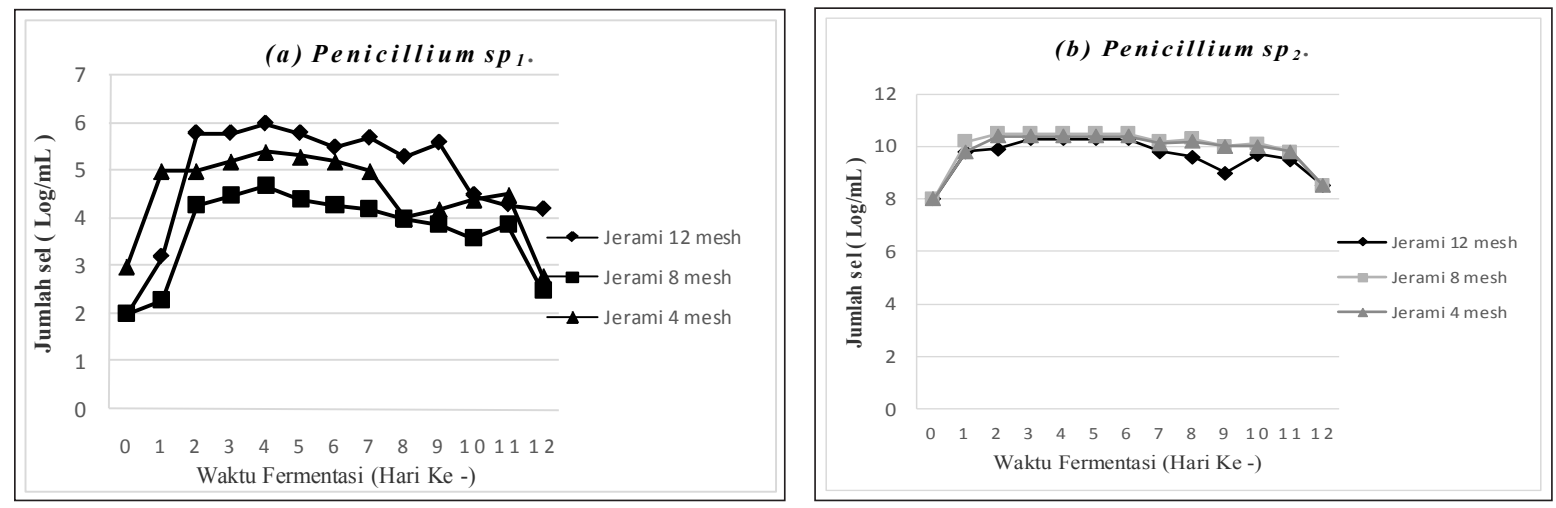

Gambar 1. Profil Pertumbuhan Jamur dalam Proses Biodegradasi Jerami Padi pada Berbagai Ukuran Jerami (a). Penicillium sp1.; (b). Penicillium sp2. 

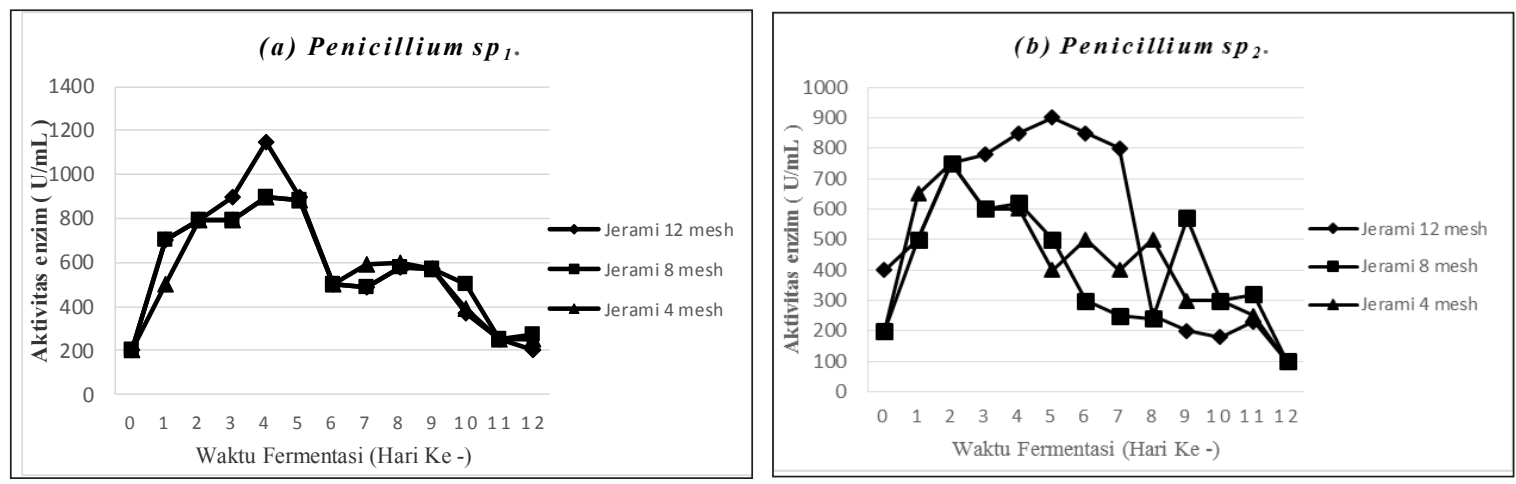

Gambar 2. Profil Produksi Ligninase dalam Proses Biodegradasi Jerami Padi pada Berbagai Ukuran Jerami (a). Penicillium sp1. (b). Penicillium sp2.
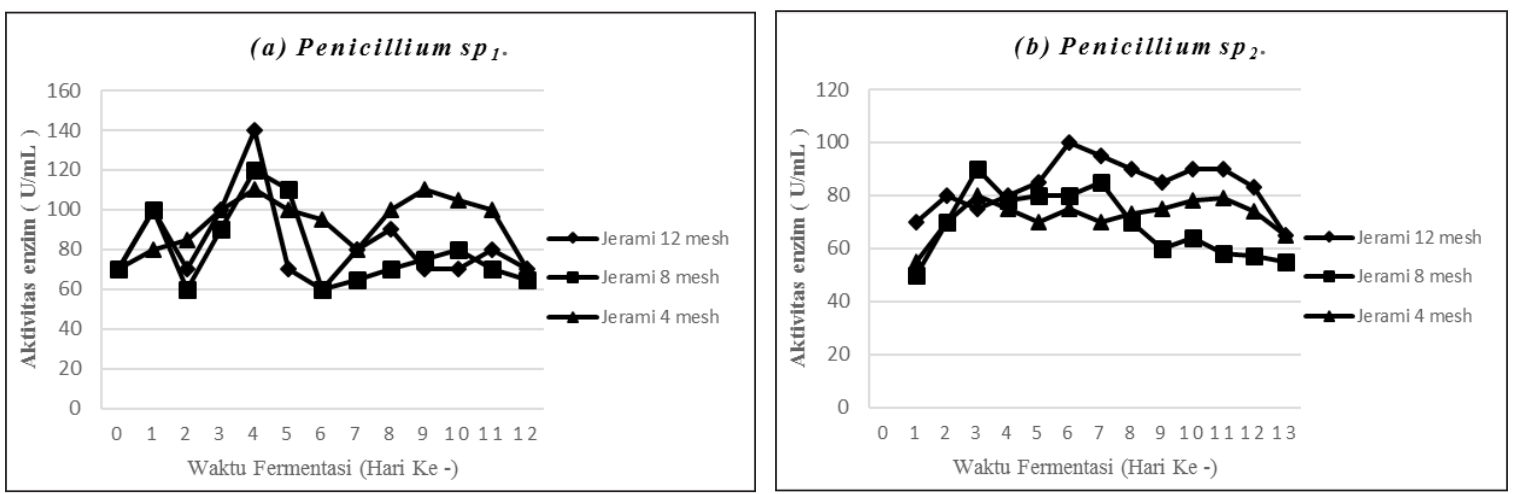

Gambar 3. Profil Produksi Selulase dalam Proses Biodegradasi Jerami Padi pada Berbagai Ukuran Jerami (a). Penicillium sp1.; (b). Penicillium sp2.

pada hari ke-4, dan cenderung menurun sampai akhir fermentasi pada hari ke-12, sedangkan Penicillium sp2. menunjukkan variasi pertumbuhan maksimum pada ukuran partikel jerami yang berbeda.

Ukuran mesh yang berbeda memberikan pola produksi ligninase yang sama dan aktivitas enzim yang dihasilkan yaitu berkisar antara 975 - 1140 $\mathrm{U} / \mathrm{mL}$. Secara kuantitas ukuran mesh terkecil yaitu 12 mesh memberikan aktivitas yang tertinggi, dengan produksi ligninase cenderung terjadi sampai akhir fermentasi pada hari ke12. Pola produksi ligninase pada Penicillium sp2. disetiap ukuran mesh yang digunakan menunjukkan pola yang berbeda, namun untuk pola produksi ligninase pada jerami berukuran 4 dan 8 mesh menunjukkan pola yang sama. Aktivitas ligninase tertinggi yang dihasilkan oleh Penicillium sp2. pada jerami berukuran 12 mesh, yaitu $882 \mathrm{U} / \mathrm{mL}$.

Profil produksi selulase dari Penicillium spp. dihasilkan dari fermentasi media padat dengan menggunakan variasi ukuran jerami 4, 8, dan 12 mesh ditampilkan pada Gambar 3. Secara umum, ukuran mesh terkecil yaitu 12 mesh memberikan aktivitas selulase yang tertinggi pada kedua isolat Penicillium.

Penicillium sp1. cenderung menunjukkan pola produksi selulase yang maksimum pada hari ke-4, dan cenderung menurun sampai akhir fermentasi pada hari ke-12, sedangkan Penicillium sp2. memberikan pola produksi selulase maksimum pada hari ke-6 terutama pada jerami berukuran 12 mesh. Penurunan aktivitas ligninase cenderung terjadi sampai akhir fermentasi pada hari ke12. Aktivitas selulase yang dihasilkan oleh Penicillium sp1. maksimum adalah $142 \mathrm{U} / \mathrm{mL}$, sedangkan untuk Penicillium sp2. menunjukkan aktivitas tertinggi adalah $102 \mathrm{U} / \mathrm{mL}$.

Ukuran partikel 12 mesh memberikan pola produksi enzim yang lebih tinggi dibandingkan ukuran partikel yang lebih besar. Ukuran partikel jerami padi yang lebih kecil menyebabkan luas permukaan partikel menjadi lebih besar, sehingga 


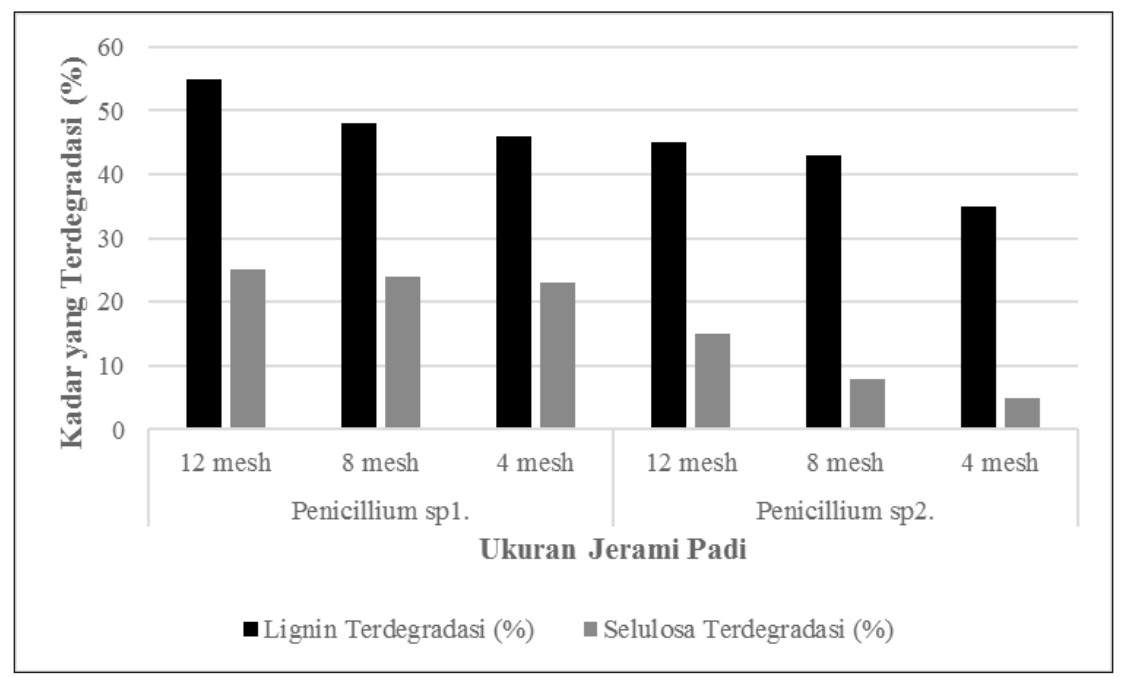

Gambar 4. Persentase Kadar Lignin dan Selulosa (a) yang Tersisa; (b) yang Terdegradasi pada Jerami Padi Hasil Proses Biodegradasi pada Berbagai Ukuran Jerami Padi

memungkinkan kontak sel jamur terutama miselumnya dengan substrat akan lebih meningkat sehingga memunculkan tingginya aktivitas enzim lignoselulase. Hal inipun didukung oleh pendapat Quintanar dkk. (2012) yang menyebutkan bahwa meningkatnya aktivitas enzim lignoselulolitik pada biomassa dapat disebabkan oleh ketersediaan substrat pada ukuran partikel yang lebih kecil dan dapat meningkatkan tingkat aksesbilitas jamur dalam substrat. Aktivitas mikroba berada di antara permukaan area jerami dan udara, dapat menentukan besarnya ruang antar bahan (porositas) sehingga permukaan area yang lebih luas akan meningkatkan kontak antara mikroba dengan substrat mengakibatkan proses dekomposisi akan berjalan lebih cepat (Nugraha dkk., 2009).

\section{Pengaruh Ukuran Partikel Jerami Padi Terhadap Kadar Lignin dan Selulosa}

\section{Hasil Analisis Kadar Lignin dan Selulosa}

Sampel jerami padi yang telah difermentasi selama 12 hari selanjutnya dianalisis komponen lignin dan selulosa yang tersisa dalam jerami padi (Gambar 4). Persentase kadar lignin dan selulosa yang tersisa pada jerami padi hasil proses biodegradasi biodegradsi jerami padi menunjukkan bahwa ukuran 12 mesh dapat meningkatkan degradasi lignin dan selulosa. Persentase kadar lignin yang terdegradasi maksimum terjadi pada jerami ukuran 12 mesh oleh Penicillium sp1., yaitu sebanyak 55,2\% yang didegradasi oleh ligninase pada aktivitas tertinggi yaitu $1140 \mathrm{U} / \mathrm{mL}$. Penelitian yang dilakukan oleh Quintanar dkk. (2012) menghasilkan informasi bahwa pengaruh ukuran partikel (8 dan 4 mesh) jerami jagung dalam proses biodelignifikasi oleh Trametes sp. 44 menunjukkan bahwa pada ukuran partikel jerami jagung 8 mesh menunjukkan aktivitas tertinggi untuk ligninase $(63 \mathrm{U} / \mathrm{mL})$, selulase $(21 \mathrm{U} / \mathrm{mL})$ dan hemiselulase $(13 \mathrm{U} / \mathrm{mL})$.

Penelitian tentang pulp dengan menggunakan bahan kimia dapat mengurangi kadar lignin sebanyak 56,41\% (Narkhede dan Vidhale, 2005). Produksi ligninase secara biopulping yang telah dilakukan oleh Arora dan Sharma (2009), yaitu dengan menggunakan jamur Phlebia brevispora memproduksi lakase sebagai enzim ekstraseluler dengan aktivitas enzim 1,9 U/ml selama 20 hari fermentasi padat (SSF) pada jerami gandum. Hasil biopulping dengan menggunakan Pycnoporus coccineus menunjukkan kadar lignin yang terdegradasi sebanyak $26,9 \%$ dengan aktivitas enzim $23 \mathrm{U} / \mathrm{mL}$ dalam waktu 60 hari (Liew dkk., 2011). Penggunaan Penicillium sp. KSt3 menghasilkan ligninase dengan aktivitas enzim 3,32 U/mL (Subowo dan Curazon, 2010). Biopulping dengan menggunakan Trametes versicolor dapat mendegradasi lignin $46 \%$ dan selulosa 23\% pada jerami gandum selama 21 hari inkubasi (Salvachua dkk., 2011). Aktivitas ligninase yang tinggi telah dilaporkan oleh Yamanaka dkk. (2008) bahwa Trametes villosa dapat menghasilkan ligninase dengan aktivitas 
731 U/L selama 14 hari. Wulandari dkk. (2013) melaporkan bahwa dengan menggunakan isolat Penicillium strain apw-tt2 yang digunakan untuk produksi pulp jerami padi memiliki aktivitas ligninase tertinggi pada hari ke-4 dengan aktivitas $553 \mathrm{U} / \mathrm{mL}$ pada suhu $40^{\circ} \mathrm{C}$ dengan metode fermentasi terendam $(\mathrm{SmF})$.

Hasil penelitian ini menunjukkan bahwa kedua isolat Penicillium spp. bila difermentasi dalam kondisimedia padatan memiliki aktivitas ligninase lebih tinggi dibandingkan dari yang pernah dilaporkan. Hal ini ini disebabkan Penicillium spp. merupakan isolat indigen yang diisolasi dari jerami yang telah dilapukkan, sehingga faktor adaptasi substrat yang terkandung pada jerami padi memungkinkan proses degradasi lignin dan selulosa dapat berlangsung efektif pada hari ke-2 hingga hari ke-4. Kemampuan Penicillium spp. dalam mendegradasi lignin dengan waktu delignifikasi yang pendek memungkinkan untuk dapat dimanfaatkan sebagai biostarter dalam proses biodegradasi jerami padi.

Hasil penelitian Wulandari dkk. (2013) menjelaskan lebih jauh bahwa dengan melakukan optimisasi suhu menjadi $40^{\circ} \mathrm{C}$ dengan metode ferementasi terendam dapat meningkatkan aktivitas enzim ligninase dari Penicillium strain apw-tt2, sehingga dapat mereduksi kandungan lignin sebanyak $66,3 \%$. Pada penelitian ini, perlakuan biodegradasi jerami padi masih dilakukan pada suhu $30^{\circ} \mathrm{C}$, dengan penggunaan Penicillium sp1. persentase kadar lignin yang terdegradasi maksimum terjadi pada ukuran jerami 12 mesh yaitu sebanyak 55,2\%, sehingga perlunya penelitian lebih lanjut dengan metode yang telah dilakukan dalam penelitian ini dengan optimisasi suhu mulai $40^{\circ} \mathrm{C}$.

\section{KESIMPULAN}

Biodegradasi jerami dipengaruhi oleh aktivitas ligninase yang optimum pada ukuran 12 mesh dengan waktu optimum 2-4 hari. Penicillium sp1. menghasilkan ligninase dengan aktivitas tertinggi $1140 \mathrm{U} / \mathrm{mL}$ dan selulase $140 \mathrm{U} / \mathrm{mL}$, sehingga dapat mendegradasi lignin sebanyak 55,2\% dan selulosa $27,6 \%$ sedangkan aktivitas tertinggi dari ligninase dan selulase dari Penicillium sp2., masing-masing adalah $882 \mathrm{U} / \mathrm{mL}$ dan $102 \mathrm{U} / \mathrm{mL}$ dengan kadar lignin yang terdegradasi adalah $49,4 \%$ dan selulosa $15,9 \%$

\section{DAFTAR PUSTAKA}

Anindyawati, T., 2010. Potensi selulase dalam mendegradasi lignoselulosa limbah pertanian untuk pupuk organik. Pusat Penelitian Bioteknologi - LIPI, Bogor

Arora, D.S., Sharma, R.K., 2009. Comparative ligninolytic potential of Phlebia species and their role in improvement of in vitro digestibility of wheat straw. Journal of Animal and Feed Sciences, 18, 151-161

Badan Pusat Statistik. 2013. Produksi padi, jagung, dan kedelai. No. 20/03/Th. XVI

Cappucino, J.G. Sherman, N., 2009. Microbiology: A laboratory manual $7^{\text {th }}$ Edition. California: The Benjamin Cummings Publishing company, Inc.

Guisado G., López, M.J., Vargas-García, M.C., Suárez-Estrella F., Moreno, J., 2001, Production of Ligninolytic Enzymes by DyeDecolorizing Microorganisms Isolated From a Composting Environment. Technologies/ systems for different manure and organic waste treatment options. (Online), www. ramiran.net/.../Ramiran2010_0075_final.pdf, diakses 24 Oktober 2014

Howard, R.L., Abotsi, E., Jansen, V.R.E.L. Howard, S., 2003. Lignocellulose biotecnology: Issues of bioconversion and enzyme production. African Journal of Biotechnology, Vol.2 (12).

Kausar, H., Sariah, M., Saud, H.M., Alam, M.Z., Ismail, M.R., 2010. Development of compatible lignocellulolytic fungal consortium for rapid composting of rice straw. Journal International Biodeterioration \& Biodegradation, 64, 594-600.

Lee, D., Owens, V.N., Boe, A., Jeranyama, P., 2007. Composition of herbaceous biomass feedstock. South Dakota State University.

Liew, C.Y., A. Husaini, H. Hussain, S. Muid, K.C. Liew and H.A. Rosian. 2011. Lignin biodegradation and ligninolytic enzyme studies during biopulping of Acacia mangium wood chips by tropical white rot fungi. World J Microbiol Biotechnol, 27, 1457-1468

Mtui, Y.S.G., 2009. Recent advance in pretreatment of lignocellulosic wastes and production of value added products. African J. of Biotechnology, Vol 8(8), 1398-1415 
Nugraha, A.W., A. Supriyanto, Ni'matuzahroh. 2009. "Isolasi dan biodegradasi limbah daduk oleh kapang selulolitik dari perkebunan tebu". Skripsi. Universitas Airlangga, Surabaya

Narkhede, K.P., Vidhale, N. N., 2005. Biopulping studies using an effluent isolate Curvularia lunata LW6. Journal Biotechnology, Vol.5, 385-388

Quintanar, G.S., Ainhoa, A.C., Flores, Y.M., Gracida, R.J.N., Alejandro, T.J., 2012. Effect of particle size and aeration on the biological delignification of corn straw using Trametes sp. 44. Journal of BioResources, 7(1), 327324

Salvachua, D., Prieto, A., Lopez-Abelairas, M., Lu-Chau, T., Martinez, A.T., 2011. Fungal pretreatment: An alternative in secondgeneration ethanol from wheat straw. Journal Bioresource Technology, 102, 7500-7506
Soares, G.M., de Amorim, M.T., Costa-Ferreira, M., 2001. Use of laccase together with redox mediators to decolourize Remazol Brilliant Blue R. J. Biotechnol., 89: 123-129

Subowo, Y.B., Corazon. 2010. Seleksi jamur tanah pengurai lignin dan PAH dari beberapa lingkungan di Bali. Berita Biologi, 10(2)

Wulandari A.P., Triyana, T., Andayaningsih, P., 2013. Delignification of rice straw with ligninase from novel Penicillium sp. strain apw-tt2 for biopulping. International Journal of Bioscience, Biochemistry and Bioinformatics, Vol. 3, No. 1

Yamanaka R., Soares, C.F., Matheus, D.R., Macado, K.M.G., 2008. Lignolytic enzymes produced by Trametes villosa CCB176 under different culture conditions. Brazilian Journal of Microbiology, 39, 78-84 